\title{
The combined influence of self-leadership and locus of control on the job performance of engineering workforce in a power generation utility: An empirical perspective
}

\begin{tabular}{|c|c|}
\hline \multicolumn{2}{|c|}{$\begin{array}{l}\text { Authors: } \\
\text { Patient Rambe }{ }^{1} \text { (D) } \\
\text { Disebo L. Modise }^{1} \\
\text { Crispen Chipunza }^{1}\end{array}$} \\
\hline \multicolumn{2}{|c|}{$\begin{array}{l}\text { Affiliations: } \\
{ }^{1} \text { Department of Business } \\
\text { Support Studies, Central } \\
\text { University of Technology, } \\
\text { South Africa }\end{array}$} \\
\hline \multicolumn{2}{|c|}{$\begin{array}{l}\text { Corresponding author: } \\
\text { Patient Rambe, } \\
\text { prambe@cut.ac.za }\end{array}$} \\
\hline \multicolumn{2}{|c|}{$\begin{array}{l}\text { Dates: } \\
\text { Received: } 25 \text { May } 2017 \\
\text { Accepted: } 14 \text { June } 2018 \\
\text { Published: } 23 \text { Aug. } 2018\end{array}$} \\
\hline \multicolumn{2}{|c|}{$\begin{array}{l}\text { How to cite this article: } \\
\text { Rambe, P., Modise, D.L., \& } \\
\text { Chipunza, C. (2018). The } \\
\text { combined influence of } \\
\text { self-leadership and } \\
\text { locus of control on the } \\
\text { job performance of } \\
\text { engineering workforce in a } \\
\text { power generation utility: } \\
\text { An empirical perspective. } \\
\text { SA Journal of Human Resource } \\
\text { Management/SA Tydskrif vir } \\
\text { Menslikehulpbronbestuur, } \\
\text { 16(0), a952. https://doi. } \\
\text { org/10.4102/sajhrm. } \\
\text { v16i0.952 }\end{array}$} \\
\hline \multicolumn{2}{|c|}{$\begin{array}{l}\text { Copyright: } \\
\text { (c) 2018. The Authors. } \\
\text { Licensee: AOSIS. This } \\
\text { is licensed under the } \\
\text { Creative Commons } \\
\text { Attribution License. }\end{array}$} \\
\hline \multicolumn{2}{|l|}{ Read online: } \\
\hline 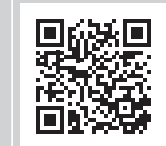 & $\begin{array}{l}\text { Scan this QR } \\
\text { code with your } \\
\text { smart phone or } \\
\text { mobile device } \\
\text { to read online. }\end{array}$ \\
\hline
\end{tabular}

Orientation: The joint effects of self-leadership and locus of control within an engineering context have been under-explored because much research focused on self-leadership and locus of control as independent concepts, and studies on their combined effects on organisational performance remain hard to encounter in emerging economies.

Research purpose: The aim of the study was to develop deeper empirical knowledge of the combined effects of self-leadership and locus of control on job performance of engineering workforce in Eskom Free State.

Motivation for the study: The originality of the study lies in the reconstitution of individual self-leadership and locus of control concepts as they relate to job performance and its impact on prospective engineers who work at Eskom in Bloemfontein.

Research approach/design and method: Drawing on a quantitative approach, a survey was conducted on 134 engineering personnel (comprising engineers, technologists and technicians). Of this workforce, a total of 107 engineers participated in the study representing a response rate of $79.8 \%$. Correlation and multiple regression analysis were used to analyse the corpus of quantitative data.

Main findings: The results demonstrate that self-leadership and locus of control are significant independent variables and when considered jointly, they have a positive significant impact on job performance of the Eskom engineering workforce.

Practical/managerial implications: Implications for the initiation and fostering of selfleadership and locus of control to improve the job performance of Eskom Bloemfontein engineering workforce are discussed.

Contribution/value-add: The study contributes to engineers' task-focused behaviour through its expectations for the engineering workforce to be self-leaders who exercise internal locus of control in the execution of their jobs. This study also contributes to engineers' work-related personality dimensions and sense of self-awareness through an exposition of individual personalities they were not conscious of.

\section{Introduction}

This empirical study examines the combined influence of self-leadership and locus of control on the job performance of the engineering workforce in a power generation utility, Eskom, Free State. Eskom Holdings SOC Limited (hereinafter referred to as 'Eskom') which is the largest public power utility responsible for the generation, transmission and distribution of electricity in South Africa. Among its core mandates, Eskom has contributed to the steering of positive economic growth, economic and social transformation, strived to reduce carbon emissions (for which it is one chief contributor) and improved the efficiency (Tsotsi, 2011) of the electricity generation and distribution programmes and projects. For the purpose of this study, self-leadership is one's intrinsic motivation to influence self, regarding what, why and how to perform work (Stewart, Courtright \& Manz, 2011). Locus of control is a psychological concept that refers to how strongly people believe they have control over situations and experiences that affect their lives. However, self-leadership is impossible without an internal locus of control (Adams, Kalliny, De los Santos, \& Wang, 2008; McDevitt, Giapponi, \& Tromley, 2007). Similarly, Thomas, Kelly and Lillian (2006) report a strong connection between employees' regulation or control of their actions 
(i.e. locus of control) and the consequences of those actions in the work environment (e.g. successful job performance).

There is a convergence of literature on the role of selfleadership and locus of control in improving organisational performance (Dewettinck \& van Ameijde, 2011; Kalyar, 2011; Neck \& Houghton, 2006; Schermuly \& Meyer, 2011; Sharma \& Kaur, 2011). However, the multiplicity of challenges experienced at Eskom seems to be inconsistent with the prevalence and exertion of self-leadership and internal locus of control at this institution. These challenges include continuous blackouts attributed to poor projections of electricity demands, infrastructural project completion delays leading to cost overruns, project scope creep and increased electricity tariffs to avoid load shedding. As such, the combined influence of self-leadership and locus of control of the engineering workforce at Eskom, Bloemfontein on job performance needs examination to ensure effective delivery of electricity services in South Africa. Therefore, this study seeks to address the following question:

- What is the combined influence of self-leadership and locus of control of the Eskom engineering workforce on their job performance?

\section{Problem statement}

Electricity is regarded as a pivotal component and enabler of mining, industrial, commercial and domestic activities that drive economic growth opportunities and enhance decent living for all South Africa's citizens. By the same token, the Republic of South Africa's National Development Plan (which aims to eliminate poverty and reduce inequality) portrays electricity as an important component of a development framework that would assist society in achieving decent standards of living (National Planning Commission, 2012). Mindful of this profound importance of electricity for human development and survival, it is unsurprising that the South African government is the sole shareholder of Eskom that directs this organisation's actions to ensure the achievement of its strategic objectives (Eskom Holdings SOC Ltd, 2013a).

Eskom's underperformance has been interpreted as a consequence of multiple factors. These factors include serious and persistent failures of electricity supply leadership by the board of Eskom, leadership failures in government, lack of capacity by Eskom and government with regard to negotiating a successful private sector partnership for new generation capacity and Eskom management's poor response to the difficult situation (Business Tech, 2015; CDE Round Table, 2008). Constraints within leadership manifested in the Eskom Board's failure to provide skilled and independent leadership to Eskom's management in dealing with coal procurement issues and the energy mix, and in the decade-long failure to communicate effectively with government and the public about the urgent need to build more power stations (CDE Round Table, 2008). This conundrum was compounded further by the leadership crisis at Eskom as recently noted in the suspension of Eskom's Chief Executive Officer (CEO), three other senior executives and the Financial Director, to allow for the Eskom Board Chairman's inquiry into the operations of the utility without their interference (Business Tech, 2015). The lack of capacity at Eskom and in the government resulted in their failure to contract international and local contractors to build a single plant in seven years (2001-2007) (CDE Round Table, 2008) long after the electricity crisis in South Africa had been predicted by the African National Congress cabinet in 1998.

The leadership crisis at Eskom recently manifested in the suspension of Eskom's CEO, three other senior executives and the Financial Director, to allow for the Eskom Board Chairman's inquiry into the operations of the utility without their interference (Business Tech, 2015). In 2016, the CEO of Eskom resigned under controversial circumstances over allegations of irregularities and corruption involving the awarding of tenders for procuring coal to fire Eskom's power plants.

Despite the aforementioned challenge's demonstration of the inseparable connection of self-leadership and locus of control, these concepts and their impact on job performance are often explored as independent subjects. For instance, a demonstration of self-leadership by management is considered to modify employees' perceptions of aspects of organisational culture such as social irresponsibility and minimise the associated negative effects that lead to undesirable behaviours among organisational employees (Pearce \& Manz, 2011). By the same token, because internal locus of control is postulated to have a positive relationship with performance (Thomas et al., 2006), fostering internal locus of control among employees of an organisation can optimise the productivity of the organisation. Although internal locus of control may positively impact performance of an organisation, such impact cannot be assumed to be universal as other critical variables (e.g. self-leadership) are also implicated in organisational performance. However, to our knowledge, the combined effects of locus of control and self-leadership on organisational performance remain unknown in developing economies as no systematic study has been conducted to date on these issues. Fostering high levels of self-leadership and internal locus of control can contribute to the overcoming of organisational cultures that impede innovation (Prattom \& Savatsomboon, 2012) and the optimisation of organisational performance. Therefore, the problem is our limited knowledge of the combined effects of self-leadership and locus of control on the job performance of the engineering workforce.

\section{Literature review}

\section{Definition of self-leadership}

Self-leadership has been explored by different authors who came up with different characterisations of the term, and different studies on the concept across different contexts have generated different results (Elloy, 2008). The concept, which first emerged in the mid-1980s (Manz, 1983, 1986) as an 
expansion of self-management (Manz \& Sims, 1980), was rooted in the clinical self-control theory (Cautela, 1969). Self-leadership is inspired by Kerr and Jermier's (1978) notion of 'substitutes for leadership', which describes situational factors that may 'neutralise' leadership or prevent a leader from taking action in particular situations. Stewart et al. (2011) define self-leadership as the process of self-motivating and self-determining one's actions through specific behavioural and cognitive methods.

Self-leadership consists of three distinct but complimentary strategies - behaviour-focused, natural reward, and constructive-thought pattern - strategies through which people control their own actions and thinking to reach personal and organisational goals (Manz \& Sims, 2001; Neck \& Manz, 2010; Prussia, Anderson, \& Manz, 1998).

Behaviour-focused strategies are related to a set of self-influence strategies proposed by early self-management scholars (Manz \& Sims, 1980). These strategies operate within the framework of Bandura's (1986) social learning theory, which argues that a person's behaviour is influenced not only by external environmental factors but also by the individual's self-regulation processes. Based on the premise of social learning theory, Manz and Sims (1980) highlight various self-management strategies such as self-goal setting, selfobservation, self-reward, self-punishment and self-cueing (Manz, 1986; Neck \& Manz, 2010) that are used by individuals to manage their goal-striving behaviours.

Natural reward strategies involve building more pleasant and enjoyable features into goal-striving actions as well as shaping one's perceptions by focusing attention on the rewarding aspect rather than the unpleasant features of tasks (Manz \& Sims, 2001; Neck \& Manz, 2010).

Constructive-thought strategies focus on the formation of constructive thought patterns that can positively impact performance (Neck \& Manz, 2010). They include evaluating beliefs and assumptions, the use of mental imagery and positive self-talk.

\section{Studies of self-leadership}

Van Zyl (2013) examines self-leadership and happiness within the South African working context (schools, manufacturing, mining and electricity sectors). The study reports that selfleadership can affect happiness within the African working context and the integration of this concept into traditional African values and beliefs can contribute to employees' achievement of their full work potential. Another study conducted by Jooste and Roux (2014) examines the practice of self-leadership in personal and professional development of contract nursing staff in a higher education institution. The study revealed that contract staff feel undervalued by the organisation and job insecurity and fewer benefits undermine their motivation and self-leadership within the organisation. The study also revealed that contract employees' exertion of self-leadership enables the regulation of their own actions, personally and professionally. It can be inferred that while organisational environment can undermine the pursuit of selfleadership, personal agency could be fundamental to the realisation of self-leadership.

\section{Implications of self-leadership on job performance}

Research evidence links organisational success to various features of leadership, such as self-leadership (Houghton, Dawley \& DiLiello, 2012). Be that as it may, the self-leadership -performance relationship is not a clear and straightforward one. Goldman, Wesner, and Karnchanomai (2013) warn that although organisations make huge financial investments into leadership development programmes, the benefits for organisations and individuals who complete these programmes are not yet discernible or well understood. At a team level, most studies on self-leadership focused on task performance to understand the role of self-leadership in achieving a high level of team performance aspects such as proficiency, adaption or proactivity (Hauschildt \& Konradt, 2012). In a German business context, Hauschildt and Konradt (2012) conducted an empirical study on self-leadership and team members' work role performance and reported that selfleadership is positively related to adaption and proactivity at the individual and team task level.

\section{Definition of locus of control}

Julian Rotter first developed the concept 'Locus of Control'. Locus of control according to Rotter (1966) refers to a personality dimension that helps explain one's behaviour. It refers to the perception of one's capacity to influence work or life outcomes and the extent to which people believe that they can control the events that affect them. Locus of control is defined as a person's tendency to see events as being controlled internally or externally (Rotter, 1966; Shojaee \& French, 2014). This tendency characterises a person's perspective on selfindependence in contrast to control by others. Locus of control also determines the likelihood of a particular behaviour as well as the outcomes of engaging in such behaviour (April, Dharani, \& Peters, 2012). In the context of an engineering environment, locus of control describes the capacity of engineers to shape and influence work-related outcomes such as engineering drawing, maintenance of substations and execution of technical tasks such as restoration of power in customers' houses.

Locus of control can be categorised into internal and external locus of control. The individuals with internal locus of control have the belief that they can monitor the events or situations with their own fate and have a strong belief in themselves and their abilities (Zaidi \& Mohsin, 2013). Therefore, such individuals discern clear connections between their actions and outcomes of their behaviours. In contrast, individuals with external locus of control attribute events and situations to the external circumstances rather than to their own capabilities. Therefore, they believe that the events affecting their lives cannot be predicted and controlled (Kücükkaragöz, 1998; Rastegar \& Heidari, 2013) as they are consequences of a complex, dynamic external environment. 


\section{Studies of locus of control}

Hans, Mubeen and Ghabshi (2014) conducted a study on locus of control and job satisfaction in private international schools in the Sultanate of Oman. The findings revealed that teachers at private international schools were primarily driven by internal locus of control and their level of job satisfaction was high.

Another study conducted by Mustafa (2011) examined the goal orientations, locus of control and academic achievement of prospective teachers in different majors at the Faculty of Education in Pamukkale University in Turkey. The results show that mastery goal orientation was positively related with locus of control $(r=0.35 ; p<0.01)$ and academic achievement $(r=0.15 ; p<0.05)$ and avoidance goal orientation was negatively related with locus of control $(r=-0.21 ; p<0.01)$ and academic achievement $(r=-0.19 ; p<0.01)$. A positive relationship was found between locus of control and academic achievement $(r=0.14 ; p<0.05)$. The results obtained in this study suggest that the teachers should stimulate their students to develop and use internal locus of control and mastery goal orientation to increase their academic performance. More so, they need to enhance internal locus of control for them to become good mastery learners.

\section{Implications of locus of control for job performance}

Many researchers have shown that locus of control is related to performance (Sonnentage, Volmer, \& Spychala, 2010; Spector, 1982; Spector \& O'Connell, 1994).

Wang, Bowling and Eschleman (2010) found that individuals with an internal locus of control orientation appear more motivated, perform better on the job and express higher levels of satisfaction than individuals with an external locus of control. Literature (Chen \& Silverthorne, 2008; Asgari \& Varkiri, 2012) states that locus of control has been found to be positively associated with low perceived stress and high performance. If individuals with internal locus of control are found to take charge, perform better on complex tasks, are easier to motivate and exercise a higher degree of initiative than externals, as much of the research using Rotter's I-E questionnaire suggests, then it is reasonable to expect such individuals to demonstrate higher performance ratings and maintain a significantly greater performance average on their jobs than those with external locus of control. Several studies support the notion that internals (people with internal locus of control) exert greater effort on the job and are subsequently better performers (Asgari \& Vakiri, 2012; Muhonen \& Torkelson, 2004; Thomas et al., 2006) than externals (people with external locus of control).

\section{Combined influence of self-leadership and locus of control on job performance}

The importance of the self-leader - locus of control performance relationship arises from the contribution of followers to the leadership process as followers are integral to the performance of leadership (Verwey, Du Plessis, \& Van der Merwe, 2013). Because self-leadership emphasises one's intrinsic motivation towards work (Stewart et al., 2011), it can be conceived to directly feed into perceptions about one's capacity to influence his or her work-related outcomes and, therefore, improve performance of large organisations. As such, self-leadership is impossible without an internal locus of control and innovation (Adams et al., 2008; McDevitt et al., 2007). It can be inferred from the aforementioned discussion that a combination of self-leadership and internal locus of control is critical in achieving high job performance for engineers through increased proficiency, adaptation or proactivity and the ability to multitask in the face of competing tasks and work activities.

\section{Methodology Research design}

A research design details the procedures necessary for collection, measurement and analysis of data, which helps the researcher to structure or solve research problems (Sreejesh, Mohapatra, \& Anusree, 2014).

A survey design was adopted in this study to explore Eskom engineers' perceptions of the importance of being a selfleader and having internal locus of control and the implications of such traits for job performance. Because surveys are ideal for collecting information from large groups of individuals at minimum cost, this design cohered with the researchers' intentions to collect data from a large engineering workforce comprising engineers, technologists and technicians at Eskom, Bloemfontein.

\section{Target population}

The population comprised 134 full-time engineering workforce $(N=134)$ from Eskom Free State departments where the study was carried out. Of the 134 engineering workforce, there were 30 full-time graduate engineers, 34 technologists and 70 technicians. Given the small size of the population of engineers, technologists and technicians at Eskom, Bloemfontein, a census involving all members of this workforce, was considered. A census is considered appropriate when the entire population is very small and hence it becomes necessary to include all members of that population to all the engineering workforce, 107 questionnaires were successfully completed, representing $79.8 \%$ of the total population.

\section{Data collection}

The second author administered the survey on respondents. The process involved getting clearance from senior management at Eskom and the distribution of printed closed Likert-based questionnaires to respondents. The survey, which was administered over 2 months involved the respondents de-briefing in groups about the purpose of the study and its intended benefits. They were also apprised of their anonymity and their right to voluntarily participate in the study. While the researcher administered some of the questionnaires, those respondents who were busy were 
granted the opportunity to collect the questionnaires, complete them at times convenient to them and submit them in one office most accessible to them.

\section{Data analysis}

Descriptive and inferential statistics were employed in this study. Descriptive statistics which include frequencies and percentages were used to present demographic data. Spearman's rho correlation coefficient and regression equations were used to test the independent variables' influence on the dependent variable (i.e. job performance) and to predict their influence on job performance, respectively.

\section{Instrument credibility}

The structured questionnaire instrument was an adapted version of Rotter's Locus of Control Scale and Revised Self-Leadership Questionnaire. A reliability analysis was conducted using Cronbach's alpha coefficient. The Cronbach's alpha coefficient for internal locus of control was 0.706 and for external locus of control 0.434. The Cronbach's alpha coefficient for locus of control (overall) was 0.688. The Cronbach's alpha coefficient for self-leadership (overall) was 0.810 .

The self-leadership concept was also disaggregated into its components namely: behaviour-focused, natural rewards and constructive thoughts and the reliability analyses for these components were also calculated. The Cronbach's alpha coefficient for behaviour-focused component (overall) was 0.744 , for natural rewards 0.695 and for constructive thoughts (overall) 0.798. Based on Kumar's (2011) argument that any Cronbach's coefficient that is over 0.6 signifies a reliable measurement, these statistics demonstrate that questionnaire items were reliable.

The averages and percentages of the internal locus of control and overall locus of control variables were calculated.

TABLE 1: Descriptive statistics.

\begin{tabular}{lcc}
\hline Variables & Mean & Mean \% \\
\hline Internal locus of control & 58.41 & 77.88 \\
Locus of control (overall) & 76.02 & 69.11 \\
\hline
\end{tabular}

TABLE 2: Descriptive statistics of self-leadership.

\begin{tabular}{lcc}
\hline Variables & Mean & Mean \% \\
\hline Behaviour-focused (components) & & \\
$\quad$ Self-goal setting & 21.24 & 84.97 \\
Self-reward & 10.58 & 70.53 \\
Self-observation & 16.75 & 83.74 \\
Self-cueing & 11.42 & 76.14 \\
Self-punishment & 20.09 & 66.98 \\
Behaviour-focused (overall) & 80.08 & 76.27 \\
Natural rewards & & \\
$\quad$ Natural rewards & 16.56 & 82.80 \\
Constructive thought (components) & & \\
$\quad$ Self-talk & 7.62 & 76.17 \\
Evaluating beliefs and assumptions & 11.65 & 77.69 \\
Constructive thought (overall) & 19.27 & 77.08 \\
Self-leadership (overall) & 115.92 & 77.28 \\
\hline
\end{tabular}

The average and percentages of self-leadership overall and its components were also calculated. The means and mean percentages of each of the items are presented in Tables 1 and 2 , respectively.

The mean percentages of internal locus of control and overall locus of control were $77.88 \%$ and $69.11 \%$, respectively. These measures were all high and above $50.00 \%$. This means that a majority of these engineers identify highly with the locus of control.

The mean percentages of overall self-leadership, behaviourfocused (overall), natural rewards and constructive thoughts (overall) are $77 \%, 76 \%, 82 \%$, and $77 \%$ which are all high and above $50 \%$. This means that a majority of these engineers identified highly with self-leadership, that is, they regarded themselves as self-leaders.

\section{Results \\ Profile of respondents}

Table 3 illustrates the profile of the respondents by gender, age group, ethnicity, marital status, educational level, hierarchy and their years of experience on the job.

The results in Table 3 highlight that a majority of respondents were men $(55.14 \%, n=59)$ while the remainder were women $(44.86 \%, n=48)$. Also, slightly more than a third $(38.32 \%)$ of the respondents were in the 21-30 years of age category, followed by those who were 41 years of age and above $(31.78 \%, n=34)$ and lastly $31-40$ years of age $(29.91 \%, n=32)$ group, respectively. About $65.42 \%$ of the respondents were black Africans, $27.36 \%$ were white and $7.55 \%$ were Indians and other minority groups.

TABLE 3: Demographic information.

\begin{tabular}{llcc}
\hline Demographic information & Category & Frequency & Percentage \\
\hline Gender & Female & 48 & 44.86 \\
& Male & 59 & 55.14 \\
Age group & $21-30$ years & 41 & 38.32 \\
& $31-40$ years & 32 & 29.91 \\
& 41 years and above & 34 & 31.78 \\
Ethnicity & Black Africans & 70 & 65.42 \\
& White & 29 & 27.36 \\
& Indian and others & 8 & 7.55 \\
Marital status $\dagger$ & Single & 44 & 41.12 \\
& Married & 63 & 58.88 \\
Educational level & Matric and certificate & 9 & 8.41 \\
& Diploma & 33 & 30.84 \\
& Honours & 21 & 19.63 \\
& Masters & 14 & 13.08 \\
& Others & 30 & 28.04 \\
Engineers hierarchy & Technicians & 50 & 46.73 \\
& Technologist & 28 & 26.17 \\
Years of experience & Graduate Engineer & 29 & 27.10 \\
on the job & 0-5 years & 27 & 25.23 \\
& 6-10 years & 28 & 26.17 \\
\hline & 11-15 years & 24 & 22.43 \\
& Over 15 years & 28 & 26.17 \\
\hline
\end{tabular}

$\dagger$, Combined never married, divorced and/or separated and widowed and named it single. This is for more plausible comparability for marital status groups. 
In addition, $41.12 \%$ of the respondents were never married, divorced and/or separated or widowed while $58.88 \%$ were married. A sizable percentage of the respondents (30.84\%) had diplomas, while $28.04 \%$ had other qualifications, $19.63 \%$ $(n=21)$ had honours degrees and a further $(13.04 \%, n=14)$ had master's degrees. Lastly, the results indicate that $46.73 \%$ of the respondents were technicians, with $27.10 \%$ being graduate engineers and a small percentage $(26.17 \%)$ were technologists.

\section{Regression analysis}

Having established the information above, the next step was determining the relationship among self-leadership, locus of control and job performance. The following regression equation was conducted.

A regression equation with job performance as a dependent variable and locus of control as the independent variable was created. This regression sought to determine the impact that locus of control has on job performance. The results are reported in Table 4.

The results show that locus of control has a positive impact on job performance. The coefficient, 0.157 , means that an improvement on locus of control by $1.0 \%$ leads to a $15.7 \%$ increase in job performance. $R$ squared is 0.162 , which means that about $16.2 \%$ of the variation in job performance is explained by locus of control.

A regression equation with job performance as a dependent variable and self-leadership as the independent variable was constructed. This regression sought to determine the impact that the components of self-leadership have on job performance. The results are reported in Table 5.

The results in Table 5 show that behaviour-focused selfleadership and constructive thought were the only significant independent variables. They have a positive impact on job performance.

A regression equation with job performance as a dependent variable and a combination of locus of control and

\begin{tabular}{lcccc} 
TABLE 4: Regression results (locus of control only). & & \\
\hline $\begin{array}{l}\text { Dependent variable: } \\
\text { Performance }\end{array}$ & \multicolumn{2}{c}{ Unstandardised } & \multirow{2}{*}{-statistic } & \multirow{p}{*}{-value } \\
\cline { 2 - 3 } & Coefficients & Std. Error & & \\
\hline Intercept & 8.683 & 2.675 & 3.246 & 0.002 \\
Locus of control & 0.157 & 0.035 & 4.499 & 0.000 \\
$R$ Square & 0.162 & - & - & - \\
\hline
\end{tabular}

Std., standard.

TABLE 5: Regression results (self-leadership components).

\begin{tabular}{|c|c|c|c|c|c|}
\hline \multirow{2}{*}{$\begin{array}{l}\text { Dependent variable: } \\
\text { Performance }\end{array}$} & \multicolumn{2}{|c|}{ Unstandardised } & \multirow{2}{*}{$\begin{array}{l}\text { Standardised } \\
\text { coefficients }\end{array}$} & \multirow[t]{2}{*}{$t$-statistic } & \multirow[t]{2}{*}{$p$-value } \\
\hline & Coefficients & Std. Error & & & \\
\hline Intercept & 9.136 & 1.782 & - & 5.127 & 0.000 \\
\hline Behaviour-focused & 0.104 & 0.023 & 0.418 & 4.562 & 0.000 \\
\hline Constructive thought & 0.167 & 0.074 & 0.206 & 2.246 & 0.027 \\
\hline Adjusted $R$ square & 0.277 & - & - & - & - \\
\hline
\end{tabular}

Std., standard. self-leadership as the independent variables was constructed. The results are reported in Table 6 .

The results in Table 6 show that self-leadership and locus of control are significant independent variables even though both have a positive impact on job performance.

\section{Discussion on findings}

In view of the regression results of locus of control as indicated in Table 4, locus of control has a positive and statistically significant influence on job performance. This is supported by Asiedu-Appiah and Addai's study (2014) whose regression analysis examined the existence of a link between employees' locus of control and contextual performance. Their study concluded that employees with higher internal locus of control had higher contextual performance ratings than employees with external locus of control.

Furthermore, results from the regression analysis on selfleadership components (Table 5) confirm that behaviourfocused and constructive thought strategies are the only significant independent variables that have a positive impact on job performance. Because self-leadership is conceptualised as an intrapersonal process for influencing oneself (Manz, 1986; Manz \& Neck, 2004; Sahin, 2011), it is not surprising that previous research has shown that each component of selfleadership contributes to performance (Neck \& Houghton, 2006). For example, Neck and Manz (1992) found that individuals who received training in the constructive-thought pattern strategies experienced enhanced states of positive affect (enthusiasm) and job satisfaction as well as a decreased state of nervousness relative to those who had not received such training. The behaviour-focused coefficient of 0.104 means that an improvement in behaviour-focused selfleadership by $1.0 \%$ will lead to a $10.4 \%$ increase in job performance. Moreover, the constructive thought coefficient of 0.167 means that an improvement in constructive thought leadership by $1.0 \%$ will lead to a $16.7 \%$ increase in job performance. Although the behaviour-focused and constructive thought strategies were not very large, they were a statistically significant and positive influence on job performance. This finding is corroborated by findings from literature. A study conducted by Politis (2006) established a direct, positive and significant relationship between behavioural-focused strategies and job satisfaction. It has usually been suggested that an individual who exhibits self-leadership behaviour is more likely to improve his or her performance with contributions to the organisational performance than an individual who does not exhibit self-leadership behaviours (Neck \& Houghton, 2006; Neck \& Manz, 1996).

TABLE 6: Regression results (both locus of control and self-leadership).

\begin{tabular}{lcccccc}
\hline $\begin{array}{l}\text { Dependent variable: } \\
\text { Performance }\end{array}$ & \multicolumn{3}{c}{ Unstandardised } & $\begin{array}{c}\text { Standardised } \\
\text { coefficients }\end{array}$ & $\boldsymbol{t}$-statistic & $\boldsymbol{p}$-value \\
\cline { 2 - 6 } & Coefficients & Std. Error & & & \\
\hline Intercept & 4.319 & 2.600 & - & 1.661 & 0.100 \\
Self-leadership & 0.085 & 0.018 & 0.429 & 4.774 & 0.000 \\
Locus of control & 0.086 & 0.035 & 0.219 & 2.432 & 0.017 \\
Adjusted $R$ square & 0.299 & - & - & - & - \\
\hline
\end{tabular}

Std., standard. 
The standardised coefficients in Table 5 show the marginal contributions of each variable to job performance and they help determine which of the independent variables are the most important. Behaviour-focused leadership has a standardised coefficient of 0.418 and constructive thought has a standardised coefficient of 0.206 . This means that behaviourfocused leadership exerts a larger positive influence on job performance than constructive thought. The $R$ square value is 0.277 , which means that about $27.7 \%$ of the variation in job performance is explained by behaviour-focused leadership and constructive thought.

Our finding (Table 6) on how locus of control and job performance are connected to performance resonates with mainstream literature. The self-leadership coefficient was 0.085, implying that an improvement in self-leadership of $1.0 \%$ leads to an $8.5 \%$ increase in job performance. The locus of control coefficient was 0.086 , which means that an improvement in locus of control of $1 \%$ will increase the job performance of the engineering workforce by $8.6 \%$. When self-leadership and locus of control are considered jointly, they explain $29.9 \%$ of the variation in job performance. This is consistent with the literature review, which reports that self-leadership is impossible without locus of control (Adams et al., 2008; McDevitt et al., 2007).

The self-leadership contribution to locus of control - job performance is also widely supported by literature. These findings corroborate evidence from mainstream literature on the significant role of self-leadership in improving organisational performance (Dewettinck \& van Ameijde, 2011; Kalyar, 2011; Schermuly \& Meyer, 2011). Moreover, the locus of control coefficient of 0.086 implies that an increase in locus of control of $1 \%$ will lead to $8.6 \%$ increase in job performance. Thomas et al. (2006) report a strong connection between employees' regulation or control of their actions (i.e. locus of control) and the consequences of those actions in the work environment (e.g. successful job performance). The standardised coefficients show the marginal contributions of each variable to job performance and assist in determining which of the independent variables are the most important. Self-leadership has a standardised coefficient of 0.429 and the locus of control has a standardised coefficient of 0.219 . This means that self-leadership has a larger contribution to job performance than locus of control. The $R$ square value is 0.299 , which means that about $29.9 \%$ of the variation in job performance is explained by self-leadership and locus of control. The findings on regression analysis (Table 6) led to the conclusion that there is a positive relationship among self-leadership, locus of control and job performance even though the effect of the relationship as shown in the above tables is moderately strong.

\section{Implications}

The fact that self-leadership and locus of control are regarded as self-influence behaviour that directs an individual towards performance when working indicates that managers need to develop a wider awareness of these concepts within the work environment to increase the self-conscious actions that affect employee productivity in the work environment. This will enable the employees to understand and identify with a strong leadership culture of an organisation to improve innovation and productivity with the organisation.

Given that self-leadership had a comparatively strong influence on job performance in comparison with locus of control, there is need for senior leadership to emphasise employees' self-leadership if improved job performance is to be sustainably maintained. Even though locus of control should not be ignored completely, more attention should be devoted to self-leadership.

Even though locus of control accounted for a small percentage (i.e. $16.2 \%$ ) of the variations in job performance of the engineering workforce, this figure could be conceived as critical and cannot be ignored. Because our study did not necessarily differentiate the impact of internal locus of control from external locus of control, it would be important for the management of Eskom to delineate the possible performance differences arising from these forms of locus of control. Specific focus could be paid to environmental conditions (work environment, supervisory approaches, training and development) as they relate to job performance and compare them to performance arising from individual psychological dispositions (personal agency, self-efficacy).

Because considerable variations in job performance were consequences of the combined influence of self-leadership and locus of control, perhaps there is need for Eskom management to consider self-leadership within this organisation in conjunction with locus of control. This can take the form of infusion of components of these constructs into their staff development and training at both managerial and operational levels. Such concepts should be infused into the operational practices of engineers, technologists and technicians within the organisation. For instance, the expression of self-leadership by the engineering workforce may require that Eskom engineers do not only have to cooperate and follow the lead of their superiors but rather demonstrate self-leadership by challenging or resisting problematic and inappropriate leadership strategies implemented by their leaders.

\section{Limitations and directions for future research}

Because the study adopts a survey approach, this may mean that the results might have limited applicability to other related electricity utilities across the country. The sample size and uniqueness of conditions that obtain at Eskom in the Free State may not resonate with those at other power distribution stations. Thus, expanding the focus of investigation to cover other power generators across the country may improve the generalisability of results.

Given that exploratory studies, such as the current one are based on perceptions of respondents from the Eskom workforce at a particular time when the research was conducted, there is no guarantee of replicability of this study in the future as a result of an evolution of staff views 
on locus of control and self-leadership as conditions at Eskom change over time. That said, this study can be conceived as an accurate presentation of the perceptions of Eskom, Bloemfontein engineering workforce at the time this study was conducted.

This study focused on only one public power generation and distribution utility. It is important to take into consideration that this power utility, in its own way, is unique from other power utilities in terms of its structure, communication systems and management style. Besides, the study focuses on engineers exclusively. Thus, a larger sample of employees, including senior management, would allow a broader representation of the views on the matters investigated in this study, which will increase the extent of generalisability of results.

\section{Conclusion}

The findings revealed that a combination of self-leadership and internal locus of control is critical to achieving high job performance of engineers. Such performance could emerge from increased proficiency, proactivity and multitasking in the face of competing tasks and work activities. It is recommended that behaviour-focused and constructive thought pattern stratergies need to be aligned with internal locus of control behaviours to guarantee improved job performance of the engineering workforce at Eskom Bloemfontein. Behaviour-focused strategies, which emphasise observation and change of the engineers' own behaviour through primary factor strategies, could emphasise a strong customer orientation through proactive work order handling, prioritisation of customer needs, efficient and effective resource (money, time and energy) allocation, rapid response strategies to field services, fault management, control centre and flexing of work requirements in view of resource constraints. Finally, constructive thought process would cover all the 'head work' required in design engineering, alignment of technical drawings to industrial and ISO (International Organisation for Standardisation) standards, plant life cycle management and maintenance.

\section{Acknowledgements}

The authors are grateful to the Eskom Bloemfontein engineering workforce for their participation in the survey and to Eskom Senior Management for granting them permission to conduct the study in their organisation. The authors also thank the Central University of Technology, Free State, for funding this study.

\section{Competing interests}

The authors declare that they have no financial or personal relationships that may have inappropriately influenced them in writing this article.

\section{Authors' contributions}

D.L.M. wrote the article. P.R. reworked the entire article and C.C. edited the final version of the article.

\section{References}

Adams, R., Kalliny, M., De los Santos, G., \& Wang, Y. (2008). Marketing implications of locus of control orientation among college students: Comparisons of Hispanic and Anglo students in the United States. The Marketing Management Journal, 15(18), 109-120.

April, K. A., Dharani, B., \& Peters, K. (2012). Impact of locus of control expectancy on level of well-being. Review of European Studies, 4(2), 124-137. https://doi. org/10.5539/res.v4n2p124

Asgari, M. H., \& Vakili, M. (2012). The relationship between locus of control, creativity and performance of the Educational Department Employees in the west of Mazandaran. International Research Journal of Applied and Basic Sciences, 3(17), 255-256.

Asiedu-Appiah, F., \& Addai, H. (2014). An investigation into the causal relationship between employees' locus of control and contextual performance. Proceedings of ASBBS Annual Conference: Las Vegas, 21(1), 40-55.

Bandura, A. (1986). Social foundations of thought and action: A social cognitive theory. Englewood Cliffs, NJ: Prentice Hall.

Business Tech. (2015). Poor load shedding plans affect businesses. Retrieved from http:// www.fin24.com/Economy/Poor-load-shedding-plans-affect-businesses-20150128

Cautela, J. R. (1969). Behaviour therapy and self-control: Techniques and applications. In C. M. Franks (Ed.), Behavioural therapy: Appraisal and status (pp. 323-340). New York: McGraw Hill.

Chen, J. C., \& Silverthorne, C. (2008). The impact of locus of control on job stress, job performance and job satisfaction in Taiwan leadership and Organisation Development. Journal of Organisational Behaviour, 29(5), 572-582.

CDE Round Table, (2008), South Africa's electricity crisis. How did we get here? And how do we put things right. Retrieved from http://www.cde.org.za/south-africa-selectricity-crisis-how-did-we-get-here-and-how-do-we-put-things-right/

Dewettinck, K., \& van Ameijde, M. (2011). Linking leadership empowerment behaviour to employee attitudes and behavioural intentions: Testing the mediating role of psychological empowerment. Personnel Review, 40(3), 284-305. https://doi.org/ 10.1108/00483481111118621

Elloy, D. F. (2008). The relationship between self-leadership behaviours and organisation variables in a self-managed work team environment. Management Research Review, 31(1), 801-810.

Eskom Holdings SOC LTD (2013a). 1923-2013, Eskom's 1st decade. Retrieved from http://www.eskomnews.com/eskomnews/history/1stdecade/\#page/2

Goldman, E., Wesner, M., \& Karnchanomai, O. (2013). Reciprocal peer coaching: A critical contributor to implementing individual leadership plans. Human Resource Development Quarterly, 24, 63-87. https://doi.org/10.1002/hrdq.21153

Hans, A., Mubeen, S. A., \& Ghabshi, A. S. A. (2014). A study on locus of control and job satisfaction in private international schools in Sultanate of Oman. Internationa Journal of Application or Innovation in Engineering and Management, 3(1), 91-98.

Hauschildt, K., \& Konradt, U. (2012). The effect of self-leadership on work role performance in teams. Leadership, 8(2), 145-168. https://doi.org/10.1177/ 1742715011429588

Houghton, J. D., Dawley, D., \& DiLiello, T. C. (2012). The abbreviated self-leadership questionnaire (ASLQ): A more concise measure of self-leadership. Internationa Journal of Leadership Studies, 7(4), 216-232.

Houghton, J. D., \& Jinkerson, D. L. (2007). Constructive thought strategies and job satisfaction: A preliminary examination. Journal of Business and Psychology, 22(9), 45-53. https://doi.org/10.1007/s10869-007-9046-9

Jooste, K., \& Roux, L. Z. (2014). The practice of self-leadership in personal and professional development of contract nursing staff in the environment of a higher education institution. African Journal for Physical, Health Education, Recreation and Dance, October(Supplement 1:1), 275-285.

Kalyar, M. N. (2011). Creativity, self-leadership and individual innovation. The Journal of Commerce, 3(3), 20-20.

Kerr, S., \& Jermier, J. M. (1978). Substitutes for leadership: Their meaning and measurement. Organization Behavior and Human Performance, 22, 375-403. https://doi.org/10.1016/0030-5073(78)90023-5

Kücükkaragöz, H. (1998). Effects of locus of control and the formation of the students control the focus of elementary school teachers. Unpublished PhD Thesis, Dokuz Eylul University, Izmir: Social Sciences Institute.

Kumar, R. (2011). Research methodology: A step-by-step guide for beginners. London: Sage.

Manz, C. C. (1983). The art of self-leadership: Strategies for personal effectiveness in your life and work. Englewood Cliffs, NJ: Prentice-Hall, Inc.

Manz, C.C. (1986). Self-leadership: Toward an expanded theory of self-influence processes in organisations. Academy of Management Review, 11(3), 585-600. https://doi.org/10.5465/amr.1986.4306232

Manz, C. C., \& Neck, C. P. (2004). Mastering self-leadership: Empowering yourself for personal excellence (3rd ed.). Upper Saddle River, NJ: Prentice-Hall.

Manz, C. C., \& Sims, H. P. (1980). Self-management as a substitute for leadership: A social learning perspective. Academy of Management Review, 5(7), 361-367. https://doi.org/10.5465/amr.1980.4288845

Manz, C. C., \& Sims, H. P. (2001). The new super leadership: Leading others to lead themselves. San Francisco, CA: Berrett-Koehler.

McDevitt, R., Giapponi, C., \& Tromley, C. (2007). A model of ethical decision-making: The integration of process and content. Journal of Business Ethics, 10(73), 219-229. 
Muhonen, T., \& Tokelson, E. (2004) Work locus of control and its relationship to health and job satisfaction from a gender perspective. Journal of Stress and Health 21(20), 21-28. https://doi.org/10.1002/smi.994

Mustafa, B. (2011). Goal orientations, locus of control and academic achievement in prospective teachers: An individual differences perspective. Education Science: Theory and Practice, 11(2), 540-546.

National Planning Commission. (2012). National Development Plan 2030. Retrieved from http://www.gov.za/sites/www.gov.za/files/Executive $\% 20$ Summary-NDP\%20 2030\%20-\%200ur\%20future $\% 20-\% 20$ make $\% 20$ it $\% 20$ work.pd

Neck, C. P., \& Houghton, J. D. (2006). Two decades of self-leadership theory and research Past developments, present trends, and future possibilities. Journal of Manageria Psychology, 21(6), 270-295. https://doi.org/10.1108/02683940610663097

Neck, C. P., \& Manz, C. C. (1992). Thought self-leadership: The impact of self-talk and mental imagery on performance. Journal of Organisational Behaviour, 12(1), 681-699. https://doi.org/10.1002/job.4030130705

Neck, C. P., \& Manz, C. C. (1996). Thought self-leadership: The impact of mental strategies training on employee behaviour, cognition, and emotion. Journal of Organisational Behaviour, 17, 445-467. https://doi.org/10.1002/(SICI)10991379(199609)17:5\%3C445:AID-JOB770\%3E3.0.CO;2-N

Neck, C. P., \& Manz, C. C. (2010). Mastering self-leadership: Empowering yourself for personal excellence (5th ed.). Upper Saddle River, NJ: Prentice Hall.

Pearce, C. L., \& Manz, C. C. (2011), Leadership centrality and corporate social irresponsibility (CSIR): The potential ameliorating effects of self and shared leadership on CSIR. Journal of Business Ethics, 1(102), 563-579.

Politis, J. D. (2006). Self-leadership behavioural-focused strategies and team performance: The mediating influence of job satisfaction. Leadership and
Organisation Development Journal, 27(3), 203-216. https://doi.org/10.1108/ Organisation Developme

Pratoom, K., \& Savatsomboon, G. (2012). Explaining factors affecting individual innovation: The case of producer group members in Thailand. Asia Pacific Journal innovation: The case of producer group members in Thailand. Asia Pacific Journa
of Management, 3(29), 1063-1087. https://doi.org/10.1007/s10490-010-9246-0

Shojaee, M., \& French, C. (2014). The relationship between mental health components and locus of control in youth. Mount Saint Vincent University. https://www. researchgate.net/publication/269798586 The Relationship_between_Mental Health_Components_and_Locus_of_Control_in_Youth

Sreejesh, S., Mohapatra, S., \& Anusree, M. (2014). Business research methods: An applied orientation. New York: Springer International Publishing

Prussia, G. E., Anderson, J. S., \& Manz, C. C. (1998). Self-leadership and performance outcomes: The mediating influence of self-efficacy. Journal of Organisational Behaviour, 19(5), 523-538. https://doi.org/10.1002/(SICI)1099-1379(199809) 19:5\%3C523::AID-JOB860\%3E3.0.CO;2-I

Rastegar, M., \& Heidari, N. (2013). The relationship between locus of control, test anxiety, and religious orientation among Iranian EFL Students. Scientific Research, 3, 73-78.
Rotter, J. B. (1966). Generalized expectancies for internal versus external control of reinforcement. Psychological Monographs: General and Applied, 80(4), 1-28. $\mathrm{https}: / /$ doi.org/10.1037/h0092976

Sahin, F. (2011). The interaction of self-leadership and psychological climate on job performance. African Journal of Business Management, 5(5), 1787-1794. Retrieved from http://www.academicjournals.org/AJBMDOI:10.5897/AJBM10.763

Sharma, M., \& Kaur, G. (2011). Workplace empowerment and organisational effectiveness: An empirical investigation of Indian banking sector. Academy of Banking Studies Journal, 10(2), 105-120.

Shojaee, M., \& French, C. (2014). The relationship between mental health components and locus of control in youth. Psychology, 5(8), 966-978. https://doi.org/10.4236/ psych.2014.58107

Sonnentag, S., Volmer, J., \& Spychala, A. (2010). Job performance. Konstanzer (Online) Publications System (KOPS). Retrieved from http://nbn-resolveing.de/urn.nbn:de: bsz:352-opus-121834

Spector, P. E. (1982). Behavior in organisations as a function of employees' locus of control. Psychological Bulletin, 30(91), 482-497. https://doi.org/10.1037/00332909.91.3.482

Spector, P., \& O'Connell, B. J. (1994). The contribution of personality traits, negative, locus of control and Type $A$ to the subsequent reports of job stressor and job strains. Journal of Occupational and Organizational Psychology, 67(1) $1-11$.

Stewart, G. L., Courtright, S. H., \& Manz, C. C. (2011). Self-leadership: A multilevel review. Journal of Management, 19(37), 185-222. https://doi.org/10.1177/ 0149206310383911

Thomas W. H. N., Kelly, L. S., \& Lillian, T. E. (2006). Locus of control at work: A metaanalysis. Journal of Organisational Behaviour, 27(2), 107-118.

Tsotsi, Z. (2011). The Eskom Factor: Chairman's reflection. Sunninghill Sandton, Johannesburg: Eskom Holdings Limited. Retrieved from http://www.eskom.co.za/ OurCompany/SustainableDevelopment/Documents/EskomFactor.pdf

Van Zyl, E. (2013). Self-leadership and Happiness within the African Working Context. Journal of Psychology, 4(2), 59-66. https://doi.org/10.1080/09764224.2013. 11885494

Verwey, A., Du Plessis, F., \& Van der Merwe, L. (2013). Leadership effectiveness and toxicity - Different perspectives. A pilot study in South Africa. Retrieved from http://whizants.co.za/wp-content/uploads/2012/06/Leadership-Effectivenessand-Toxicity_Article-2_20131025.pdf

Wang, Q., Bowling, N. A., \& Eschleman, K. J. (2010). A meta-analytic examination of work and general locus of control. Journal of Applied Psychology, 95(4), 761-780. https://doi.org/10.1037/a0017707

Zaidi, I. H., \& Mohsin, M. N. (2013). Locus of control in graduation students. International Journal of Psychological Research, 6(1), 15-20. https://doi.org/ $10.21500 / 20112084.695$ 